\title{
Anthropogenic waste products as preferred nest sites for Myrmica rubra (L.) (Hymenoptera, Formicidae)
}

\author{
Michał Michlewicz', Piotr Tryjanowski' \\ I Department of Zoology, Institute of Zoology, Poznań University of Life Sciences, Wojska Polskiego 71C, 60- \\ 625 Poznań, Poland
}

Corresponding author: Michat Michlewicz (michlewiczmichal@gmail.com)

\begin{tabular}{l} 
Academic editor: Petr Klimeš | Received 2 March 2017 | Accepted 7 June 2017 | Published 30 June 2017 \\
\hline http://zoobank.org/6A065F2F-A2D0-4B90-9A53-0B4CD5242050 \\
Citation: Michlewicz M, Tryjanowski P (2017) Anthropogenic waste products as preferred nest sites for Myrmica rubra (L.) \\
(Hymenoptera, Formicidae). Journal of Hymenoptera Research 57: 103-114. https://doi.org/10.3897/jhr.57.12491
\end{tabular}

\begin{abstract}
Sites containing anthropogenic waste products or dumps are currently treated as refugia by a lot of animal groups, including ants. In this study the population structure of Myrmica rubra (L.) ants was compared between habitats containing and lacking anthropogenic waste products. The density of colonies and individual nests, number of queens and of workers both per colony and per nest, and queen size were analyzed. Twenty plots with waste products and 20 control (natural) plots (paired, each $10 \times 10 \mathrm{~m}$ in size) were established and compared. Results show a significant increase in colony and nest density on the plots with waste compare to the control plots. However, the number of workers, queens and queen size did not differ significantly between plot types. Overall number, as well as proportion of polycalic colonies was higher on plots with waste products. These results suggest that when $M$. rubra has more potential nest site opportunities created by human activity, the density of its colonies increases. Moreover, the anthropogenic waste product are strongly preferred nest sites for this species on the human-disturbed plots, as only them were used as nest loci there in contrast to control plots.
\end{abstract}

\section{Keywords}

ants, colony structure, human pressure, modified habitat, polydomy, rubbish, nesting habit 


\section{Introduction}

Human-origin waste dumps are considered to be potential sources of pollution of water, soil and air, and cause the spread of parasites and of invasive animal and plant species (Ružičková et al. 1996). However, for some groups of animals, these waste dumps act as refugia (Oro et al. 2013, Baranová et al. 2015). Among these animals, important inhabitants of such sites include ants (Wiezik 2006).

Ants are ecologically very important insects, which have considerable and varied impacts on ecosystems (Wilson and Hölldobler 2005). They are very widespread, abundant and have a great influence on soil formation (Hölldobler and Wilson 1990, Folgarait 1998, Frouz and Jilková 2008). Ants also have great adaptive capacity when it comes to getting food resources. They are rather opportunistic and general predators and can modify their diet according to available resources (Wilson and Hölldobler 2005) and are also important herbivores (Rico-Gray and Oliveira 2007). Some species become domestic pests (Klotz et al. 2008), while others play an important role in conservation biology of other, threatened species of insects, such as butterflies (Buszko 2004).

Although the structure of ant colonies and their response to potential harmful human activities has received a lot of attention (e.g. Majer 1983, Krzysztofiak 1991, Pętal 1994, Holec and Frouz 2005), there is no study which would test for the effects of anthropogenic waste products as potential suitable nest sites on native ant populations to our best knowledge.

Apart from the size of colonies, the ants can react to the environmental factors such as temperature (Bishop et al. 2016) or latitude (connected with temperature) (Heinze et al. 2003) also by changing their morphology, including their body size. Taking this into account, it is good to investigate whether different density and colony structure may affect ant size.

The aim of the current study was to (a) compare the density of competing colonies, as well as individual nest density of Myrmica rubra (L.), a locally common ant species in Central Europe, between places containing and lacking anthropogenic waste products, (b) test if population structure (size of colonies, number of workers and of queens per colony and per nest) is different between these two habitats and (c) compare the size of queens from the two habitats in order to detect any tendencies in gyne size related to potential different densities.

This was based on hypotheses that 1) the density of colonies on plots containing anthropogenic waste products is higher, as those product can be used as nest sites and 2) the structure of colonies in both habitats is different (e.g. number of queens or workers, and the body size of queens, per colony and per nest is lower on control plots).

\section{Materials and methods}

\section{Study species}

Myrmica rubra is the most ecologically tolerant of all European Myrmica Latr. (Czechowski et al. 2012). It is found in a variety of habitats, as long as they are at 
least partially humid. The species is also commonly found in anthropogenic habitats (Czechowski et al. 2012, Radchenko et al. 2004, Radchenko and Elmes 2010), where it sometimes uses anthropogenic waste products as nest sites (M. Michlewicz, personal observation). Myrmica rubra forms colonies which are generally polygynous, sometimes polycalic and consist of up to 10,0000 workers (Czechowski et al. 2012). Klotz et al. (2008) even reported colonies consisting of 20,000 workers and 600 queens. The number of nests in polycalic colonies of M. rubra can be large and are then called "super-colonies" (Radchenko and Elmes 2010). Because of this, aggression tests, following Roulston et al. (2003), were carried out to check how many distinct colonies were present, including possible multi-nest colonies.

\section{Study sites}

This study was undertaken in NW Poland in 2014 and 2015. Locations where study plots were established were divided into two categories: 1) "control" (20 plots) and 2) containing anthropogenic waste products ( 20 plots). Each plot was, according to the methods reviewed in Pętal and Pisarski (1966), 10×10m in size. Each locality has one pair of the plots - one control and one plot with waste products, at least 50 metres apart (with a maximum of 57 metres). "Experimental" plots were those considered suitable for M. rubra and which contained anthropogenic waste products on the ground (rubbish, empty bottles, cans, tires, clothing, rubble etc.) covering about 1/5 of the plot area (i.e. $20 \mathrm{~m}^{2}$ ). Natural plots were generally similarincluding vegetation and soil structure, but lacked any anthropogenic waste products. All plots were humid grassland with whole area sparsely, but evenly covered with not very high bushes (up to ca. 3 metres) of several plant species: Salix sp., Pinus sylvestris L., Sambucus nigra L., Prunus serotina (Ehrh.). Herbaceous vegetation consist mostly of grasses [mainly Poa cf. trivialis L. and Elymus repens (L.)], with some herbs present, like Perasites hybridus (L.), Urtica dioica L., Chelidonium majus L. and others. Each plot with waste products was previously known to the first author, with a record of that rubbish has been laying there for at least three years before this study took place. Localizations, coordinates, altitude, date of examination as well as general habitat description of each of 20 localities is available in the Suppl. material 1.

\section{Sampling techniques}

Search was made for all nests of $M$. rubra at each site by the same methods, and in a similar time for each pair of the plots, to avoid seasonal differences. This species is relatively easy to identify in the field by an experienced person using a hand lens. In the field a hand lens with $10 \times$ magnification was used. Identification was subsequently confirmed in the laboratory using a stereomicroscope. Each nest was marked with small flag on which was written a unique number. Aggression tests were then carried out and actual colonies were re-marked with numbers if necessary. Aggression tests were carried 
out in the field, using plastic Petri dishes (90 $\mathrm{mm}$ in diameter), cleaned with alcohol after each test. The arenas containing different colonies were marked with different colors. The assays include 1-1 and 5-5 battles of live worker specimens. Ants presenting aggressive behavior (biting and/or stinging) were marked as members of different colonies. Each time control test, with members of the same colony, was also carried out, but no aggressive behavior were observed in these. Whole number of workers from assays were taken in account when number of workers per colony was estimated. Every colony/nest was then excavated using a shovel and put on a white sheet $(\mathrm{ca} .150 \times 150 \mathrm{~cm}$ ), then every ant from the nest was collected using an aspirator and put in a vial (or vials) containing $75 \%$ ethanol. In the laboratory the ants were counted and queens measured.

\section{Measurements}

Queen measurements were taken using Zeiss AxioCam MRc 60 N-C 2/3" 0.63× camera fitted with Zeiss SteREO Lumar.V12 stereomicroscope and AxioVision rel. 4.8 software. Measurements were taken on the base of photographs using the given software. Mesosoma length (ML) was measured as a surrogate of body size, as it is strongly correlated with queen size (Steiner et al. 2006). General aim of taking measurements was to detect any tendencies in queen size, potentially related to the different nest densities. Sixty queens from control and 60 from plots with waste products were measured, selected randomly from the whole number of queens collected from all nests.

\section{Statistical analysis}

The results were analyzed using $\mathrm{PASW}^{\oplus}$ Statistics 18 and RStudio version 3.2.3 software (R Core Team 2015). First, Shapiro-Wilk normality test was used to check normality of distributions of the variables, and because some of them have non-normal distribution a non-parametric Wilcoxon signed-rank test (comparing the effects among the paired plots) and Mann-Whitney U-test (comparing the queen size) were used. Chi-square test was used to compare proportion of polycalic colonies among the two plot kinds.

\section{Results}

\section{Colony and nests densities}

Total number of 166 colonies (47 on control and 119 on experimental plots) consisting of a total number of 196 nests (53 on control and 143 on experimental plots) was found. Statistical analysis using a Wilcoxon signed-rank test found a significant differences between both the number of colonies (Fig. $1 \mathrm{~A}$; $\mathrm{W}=16, \mathrm{P}<0.00001$ ) and nests (Fig. $1 \mathrm{~B} ; \mathrm{W}=13.5, \mathrm{P}<0.00001$ ) between control and plots with waste products. 

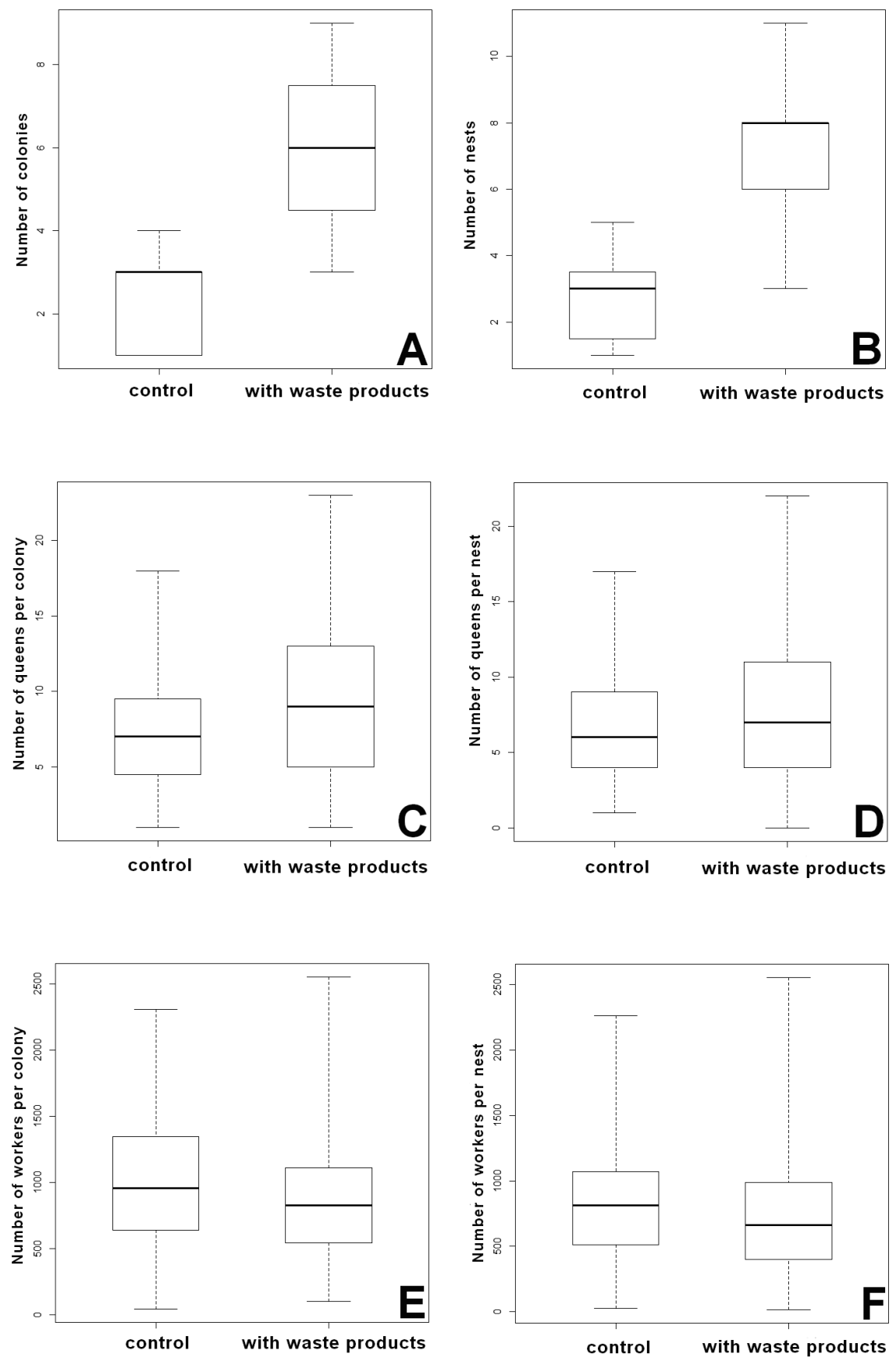

Figure I. Variation of measured nest parameters between control plots and plots with waste products in Myrmica rubra. A colony density $(\mathrm{P}<0.0001)$ B nest density $(\mathrm{P}<0.0001) \mathbf{C}$ number of queens per colony $(\mathrm{P}=0.06) \mathbf{D}$ number of queens per nest $(\mathrm{P}=0.26) \mathbf{E}$ number of workers per colony $(\mathrm{P}=0.32)$ F number of workers per nest $(\mathrm{P}=0.06)$. Numbers are given as median per plot (per $\left.100 \mathrm{~m}^{2}\right)$, whiskers of the boxplot represent the range of minimum and maximum values. 
Overall, 26 polycalic colonies was found (5 on control and 21 on experimental plots), and chi-square test found significant difference in proportion of polycalic colonies among the two plot kinds $\left(\chi^{2}=4.6493, P=0.03\right)$. Minimum number of nests in those colonies was two, while the maximum was four (one time, on plot with waste products). The mean number of colonies per plot $\left(100 \mathrm{~m}^{2}\right)$ on control areas was $2.35 \pm 0.23$ (and the mean number of nests $2.65 \pm 0.29$ ) and on plots with waste products $5.95 \pm 0.4$ for colonies and $7.25 \pm 0.44$ for nests.

\section{Colony structure and size}

\section{Number of queens}

In total, 1479 queens were sampled ( 359 from control and 1120 from plots with waste products). No "microgyne" forms were found in any nest (i.e. recognized by eye). The difference between number of queens on control and "experimental" plots both per colony (Fig. 1C) and per nest (Fig. 1D) was statistically insignificant (W = 2269.5, P $=0.06$ and $\mathrm{W}=3438.5, \mathrm{P}=0.26$, respectively), although there was a tendency of a higher queen numbers recorded in the plots with waste products. Mean queen number per colony was $7.6 \pm 0.6$ (control) and $9.4 \pm 0.47$ (plot with waste products), and per nest was $6.8 \pm 0.53$ (control) and $7.7 \pm 0.39$ (plot with waste products).

\section{Number of workers}

The difference between number of workers both per colony (Fig. 1E) and nest (Fig. 1F) on both plot types was statistically insignificant ( $\mathrm{W}=3076, \mathrm{P}=0.32$ and $\mathrm{W}=2269.5$, $\mathrm{P}=0.06$ ), although the numbers were higher on average in the control plots this time. Mean number of workers per colony on control plots with waste products was 1024.3 \pm 85.27 and $937.5 \pm 51.35$, respectively. Values for nest were $908.3 \pm 76.67$ (control) and $769.1 \pm 44.82$ (plots with waste products).

\section{Queen measurements}

The difference in size (based on mesosoma lenght) between queens from control ( $\mathrm{n}=$ 60) and experimental $(\mathrm{n}=60)$ plots was not statistically significant (Mann-Whitney U-test, $\mathrm{Z}=-0.19, \mathrm{P}=0.8493$ ) (Fig. 2). Mean size of ML of measured queens was $2.02 \pm 0.01 \mathrm{~mm}$ on control and $2.05 \pm 0.01 \mathrm{~mm}$ on plots with waste products.

\section{Nest sites}

Interestingly, on plots with waste products only these microhabitats were used as nest sites by ants. These include: empty bottles (both plastic and glass) and cans, jars, tires, clothing, bricks with holes, old carpets, plastic carrier bags, other pieces of metal or plastic, often partially covered with wet soil. On control plots $M$. rubra nests were always found in clumps of grass and/or under rocks or pieces of wood, but those microhabitats were not occupied by the species in plots with the waste. 


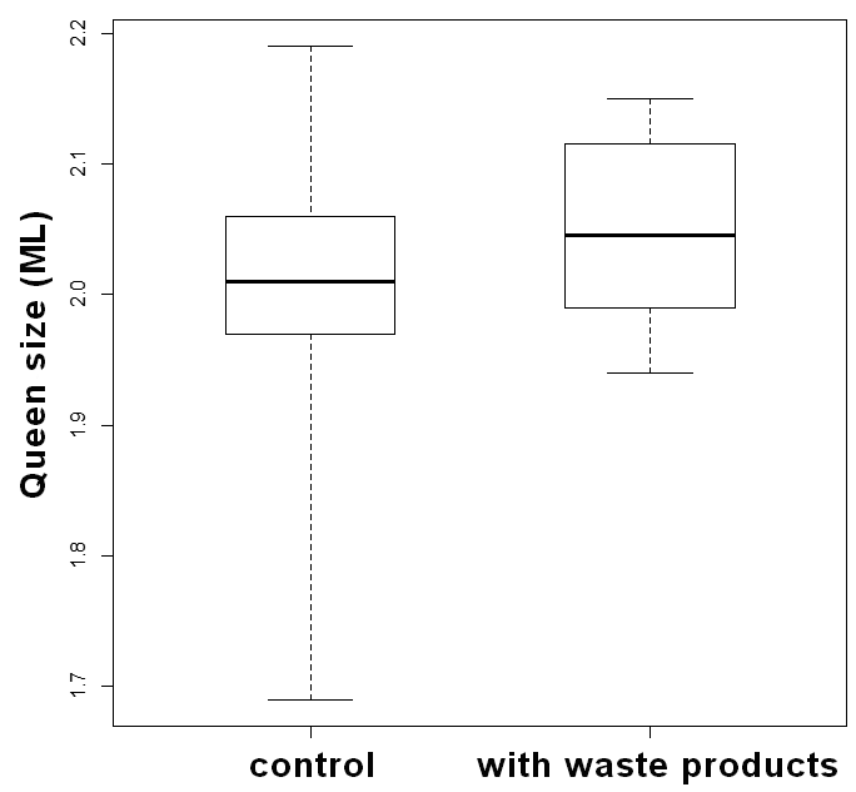

Figure 2. Variation in median queen size (mesosoma length in $\mathrm{mm}$ ) between control plots and plots with waste products in Myrmica rubra. Difference is statistically insignificant. Whiskers of the boxplot represents the range of minimum and maximum values.

\section{Discussion}

Previous studies show that in suitable humid grassland ecosystems the density of $M$. rubra nests is limited more by the number of appropriate nest sites than by the availability of food resources. When one nest site is, for some reason, abandoned by one colony, it is quickly recolonized by another of (in most cases) the same Myrmica species (Radchenko and Elmes 2010).

Concerning densities of M. rubra, only grassland habitats with no substantial volume of waste products have been studied before (e.g. Parapura and Pisarski 1971, Pętal 1980, Seppä and Walin 1996, Radchenko and Elmes 2010 and references therein, Huszár et al. 2014). Our effort is, to our knowledge, hence the first comparing nest and colonies densities, as well as workers and queens numbers (and size of the latter), on plots with and without anthropogenic waste product in order to investigate, whether those pieces of rubbish may be used by ants as nest sites and affect their populations. We showed, that anthropogenic waste products (listed in Results) can act as preferred nest loci. On plots with high level of anthropogenic waste products, only those are used as nest sites. However, increase of food resources (especially a higher quantity of small invertebrates there) may also probably affect the establishment and survival of the ant colonies in habitats with anthropogenic waste products (M. Michlewicz, personal observation), although we did not measure these parameters in our 
plots. Among studied variables, only number of colonies and number of nests on both plot types showed significant differences. Previous studies, also conducted in Poland (Czechowski et al. 2012 and references therein) showed, that densities of M. rubra nests vary greatly depending on habitat type. Therefore, it is crucial to properly choose both "experimental" and control plot within the same habitat and time to control, also for microenvironmental and seasonal characteristics, as done in this study.

To our knowledge, highest density of M. rubra in Poland was reported in the Carpathian alder forest in Pieniny National Park and equals 100 nests per $100 \mathrm{~m}^{2}$ (Czechowska 1976). Some other studies also report rather high densities, e.g. 26.0 (Parapura and Pisarski 1971), $20.5 \pm 19.3$ (Babik et al. 2009) and 20.0 (Czechowski 1985). Although, some studies did not show such high densities, e.g. $1.0 \pm 0.31$ $($ mean \pm SD) (Rzeszowski et al. 2013), 6.0 (Czechowski et al. 1990), 0.05, 3.0 and 14.0 (Pętal 1980) (all given in number of nests per $100 \mathrm{~m}^{2}$ ). Despite the fact that our results from plots with waste products (mean $7.25 \pm 0.44$ nests $/ 100 \mathrm{~m}^{2}$ ) are not as high as some literature data, this density significantly varies from results from control plots (mean $2.65 \pm 0.29$ nests $/ 100 \mathrm{~m}^{2}$ ). Notably, the "control-experimental" plot pairs were chosen in the very similar habitats (see Suppl. material 1), but only waste products were used as nest sites in the latter plots. This is a strong evidence that the increased nest and colony densities observed here were caused by the human-deposited waste, and that $M$. rubra ants prefer these waste products as nest sites, whenever available.

As some studies document, number of queens both per colony and per nest, as well as number of workers can also widely differ in Myrmica ants. Seppä and Walin (1996) report colonies consisting of mean number of 7.56 queens and 961-828 workers. Elmes (1980) reports mean number of 15.89 queens per colony and Elmes and Pętal (1990) write about overall number of workers per colony between 1,000 and 2,000. Our results on both worker and queen numbers fit those ranges. However, differences in those numbers between both plot types were insignificant. This might indicate, that living in higher densities makes $M$. rubra ants more tolerant to other colonies of the same species, but those colonies does not have to be necessary smaller (both in respect the number of workers and queens). This is in agreement with our observation of also more polycalic colonies to be established on the plots with waste products, as those colonies act behaviorally and ecologically as a single nest.

Differences in queen size between the two plot types were not statistically significant. Similar results were found by Huszár et al. (2014). This shows that living at higher density probably does not necessarily lead to changes in gyne morphology. Moreover, no "microgyne" form queens were found during the study process. However, although the queen size did not differ, there was slight tendency (insignificant) to a higher number of queens but lower number of workers per nest in the plots containing waste, which is in agreement with strategy of the ants to invest more to sexuals and to establishment of the new nest satellites, where enough "empty" nest sites is available (Oster and Wilson 1978, Poitrineau et al. 2009).

Some research showed, that where $M$. rubra forms polycalic nest systems, the number of other species of ants is significantly lower (Seppä and Pamilo 1995, Seppä and 
Walin 1996, Huszár et al. 2014). Future studies are needed to test if similar results will be found on habitats where M. rubra live in higher density because of presence of anthropogenic waste products and consider also the effects of its population increase on the other ant species. Such further insight is needed given the ongoing damage of the natural environments by humans, which can influence, however, positively some insect populations, as demonstrated here for the case of M. rubra and waste products.

\section{Acknowledgements}

PT was supported by the NCN grant N N304 294240. Queen measurements were made at the Division of Apidology, Institute of Zoology, Poznan University of Life Sciences with the kind help of Dr Aleksandra Łangowska. Our sincere thanks go to Professor Tim Sparks from Coventry University, England, for language check and other comments. We also thank to the reviewers Dr Pavel Pech (Department of Biology, University of Hradec Králové, Czech Republic), Professor Wojciech Czechowski (Museum and Institute of Zoology, Polish Academy of Sciences, Poland), and to editor Dr Petr Klimeš (Institute of Entomology, Biology Centre of the Czech Academy of Sciences, Czech Republic) for valuable and critical comments on the previous version of the manuscript.

\section{References}

Babik H, Czechowski W, Włodarczyk T, Sterzyńska M (2009) How does a strip of clearing affect the forest community of ants (Hymenoptera: Formicidae)? Fragmenta Faunistica 52: 125-141. https://doi.org/10.3161/00159301FF2009.52.2.125

Baranová B, Manko P, Jászay T (2015) Waste dumps as local biodiversity hotspots for soil macrofauna and ground beetles (Coleoptera: Carabidae) in the agricultural landscape. Ecological Engineering 81: 1-13. https://doi.org/10.1016/j.ecoleng.2015.04.023

Bishop TR, Robertson MP, Gibb H, van Rensburg BJ, Braschler B, Chown SL, Foord SH, Munyai TC, Okey I, Tshivhandekano PG, Werenkraut V, Parr CL (2016) Ant assemblages have darker and larger members in cold environments. Globe Ecology and Biogeography 25: 1489-1499. https://doi.org/10.1111/geb.12516

Buszko J (2004) Maculinea arion (Linnaeus, 1758), Maculinea teleius (Bergsträsser, 1779), Maculinea nausithous (Bergsträsser, 1779), Maculinea alcon (Denis et Schiffermüller, 1775). In: Głowacki Z, Nowacki J (Eds) Polish Red Data Book of Animals - Invertebrates. Instytut Ochrony Przyrody PAN, Akademia Rolnicza w Poznaniu, Kraków - Poznań, 248-252.

Czechowska W (1976) Myrmekofauna Pienińskiego Parku Narodowego (Hymenoptera, Formicoidea). Fragmenta Faunistica 21: 115-144. https://doi.org/10.3161/00159301 FF1976.21.5.115

Czechowski W (1985) Competition between Myrmica laevinodis Nyl. and Lasius niger (L.) (Hymenoptera, Formicoidea). Annales Zoologici 39: 153-173 
Czechowski W, Pisarski B, Czechowska W (1990) Ants (Hymenoptera, Formicoidea) of moist meadows on the Mazovian Lowland. Fragmenta Faunistica 34: 47-60. https://doi.org/10. 3161/00159301FF1990.34.4.047

Czechowski W, Radchenko A, Czechowska W, Vepsäläinen K (2012) The ants of Poland with reference to the myrmecofauna of Europe - Fauna Poloniae 4. Natura Optima Dux Foundation, Warszawa, 496 pp.

Elmes GW (1980) Queen numbers in colonies of ants of the genus Myrmica. Insectes Sociaux 27: 43-60. https://doi.org/10.1007/BF02224520

Elmes GW, Pętal J (1990) Queen number as an adaptable trait: evidence from wild populations of two red ant species (genus Myrmica). Journal of Animal Ecology 59: 675-690. https:// doi.org/10.2307/4888

Folgarait PJ (1998) Ant biodiversity and its relationship to ecosystem functioning: a review. Biodiversity and Conservation 7: 1221-1244. https://doi.org/10.1023/A:1008891901953

Frouz J, Jilková V (2008) The effect of ants on soil properties and processes (Hymenoptera: Formicidae). Myrmecological News 11: 191-199.

Heinze J, Foitzik S, Fischer B, Wanke T, Kipyatkov VE (2003) The significance of latitudinal variation in body size in a Holarctic ant, Leptothorax acervorum. Ecography 26: 349-355. https://doi.org/10.1034/j.1600-0587.2003.03478.x

Holec M, Frouz J (2005) Ant (Hymenoptera: Formicidae) communities in reclaimed and unreclaimed brown coal mining spoil dumps in the Czech Republic. Pedobiologia 49: 345-357. https://doi.org/10.1016/j.pedobi.2005.03.001

Hölldobler B, Wilson EO (1990) The Ants. Harvard University Press, Cambridge, 732 pp. https://doi.org/10.1007/978-3-662-10306-7

Huszár DB, Larsen RS, Carlsen S, Boomsma JJ, Pedersen JS (2014) Convergent development of ecological, genetic, and morphological traits in native supercolonies of the red ant Myrmica rubra. Behavioral Ecology and Sociobiology 68: 1859-1870. https://doi. org/10.1007/s00265-014-1795-7

Klotz J, Hansen L, Pospischil R, Rust M (2008) Urban Ants of North America and Europe. Identification, biology and management. Cornell University Press, Cornell, 196 pp.

Krzysztofiak L (1991) The effect of habitat pollution with heavy metals on ant populations and ant-hill soil. Ekologia Polska 39: 181-202.

Majer JD (1983) Ants: bio-indicators of minesite rehabilitation, land-use, and land conservation. Environmental management 7: 375-383. https://doi.org/10.1007/BF01866920

Oro D, Genovart M, Tavecchia G, Fowler MS, Martínez-Abraín A (2013) Ecological and evolutionary implications of food subsidies from humans. Ecology Letters 16(12): 1501-1514. https://doi.org/10.1111/ele.12187

Oster GF, Wilson EO (1978) Caste and ecology in the social insects. Princeton University Press, Princeton, 352 pp.

Parapura E, Pisarski B (1971) Mrówki (Hymenoptera, Formicidae) Bieszczadów. Fragmenta Faunistica 17: 319-356. https://doi.org/10.3161/00159301FF1971.17.13.319

Pętal J (1980) Ant populations, their regulation and effect on soil in meadows. Ekologia Polska 28: 297-326. 
Pętal J (1994) Reaction of ant communities to degradation of forest habitats in the Karkonosze Mountains. Memorabilia Zoologica 48: 171-179.

Pętal J, Pisarski B (1966) Metody ilościowe stosowane w badaniach myrmekologicznych. Ekologia Polska B 12: 363-376.

Poitrineau K, Mitesser O, Poethke HJ (2009) Workers, sexuals, or both? Optimal allocation of resources to reproduction and growth in annual insect colonies. Insectes Sociaux 56: 119-129. https://doi.org/10.1007/s00040-009-0004-6

R Core Team (2015) R: A language and environment for statistical computing. R Foundation for Statistical Computing, Vienna, Austria. https://www.R-project.org/

Radchenko A, Czechowska W, Czechowski W (2004) Błonkówki - Hymenoptera. Mrówkowate - Formicidae. Klucze do Oznaczania Owadów Polski, XXIV, Toruń, 138 pp.

Radchenko A, Elmes GW (2010) Myrmica ants (Hymenoptera: Formicidae) of the Old World Fauna Mundi 3. Natura Optima Dux Foundation, Warszawa, 789 pp.

Rico-Gray V, Oliveira PS (2007) The ecology and evolution of ant-plant interactions. University of Chicago Press, 320 pp. https://doi.org/10.7208/chicago/9780226713540.001.0001

Roulston TH, Buczkowski G, Silverma J (2003) Nestmate discrimination in ants: effect of bioassay on aggressive behavior. Insectes Sociaux 50: 151-15. https://doi.org/10.1007/ s00040-003-0624-1

Ružičková H, Halada L, Jedlička L, Kalivodová E (1996) Biotopes of Slovakia. Guide-book for Mapping and the Biotopes Catalogue. Institute of Landscape Ecology, Slovak Academy of Sciences, Stimul, Bratislava, 92 pp.

Rzeszowski K, Babik H, Czechowski W, Markó B (2013) Ants (Hymenoptera: Formicidae) of Chełmowa Góra in the Świętokrzyski National Park. Fragmenta Faunistica 56: 1-15. https://doi.org/10.3161/00159301FF2013.56.1.001

Seppä P, Pamilo P (1995) Gene flow and population viscosity in Myrmica ants. Heredity 74: 200-209. https://doi.org/10.1038/hdy.1995.28

Seppä P, Walin L (1996) Sociogenetic organization of the red ant Myrmica rubra. Behavioral Ecology and Sociobiology 38: 207-217. https://doi.org/10.1007/s002650050234

Steiner FM, Schlick-Steiner BC, Konrad H, Moder K, Christian E, Seifert B, Crozier RH, Stauffer C, Buschinger A (2006) No sympatric speciation here: multiple data sources show that the ant Myrmica microrubra is not a separate species but an alternate reproductive morph of Myrmica rubra. Journal of Evolutionary Biology 19: 777-787. https://doi. org/10.1111/j.1420-9101.2005.01053.x

Wiezik M (2006) Historical municipal waste dump in Banská Štiavnica as ants refugia in urban environment. Wastes-Bio-Degradable, Energetic and Material Utilization. Conference Text-book, Brno. [in Slovak]

Wilson EO, Hölldobler B (2005) The rise of the ants: A phylogenetic and ecological explanation. Proceedings of the National Academy of Sciences of the United States of America 102: 7411-7414. https://doi.org/10.1073/pnas.0502264102 


\section{Supplementary material I}

\section{Study sites}

Authors: Michał Michlewicz, Piotr Tryjanowski

Data type: species data

Explanation note: General description of study localities, including the dates of investigation.

Copyright notice: This dataset is made available under the Open Database License (http://opendatacommons.org/licenses/odbl/1.0/). The Open Database License $(\mathrm{ODbL})$ is a license agreement intended to allow users to freely share, modify, and use this Dataset while maintaining this same freedom for others, provided that the original source and author(s) are credited.

Link: https://doi.org/10.3897/jhr.57.12491.suppl1 